\title{
SURVEY THE NEUROPTEROUS PREDATORS AND THE RELATIVE ABUNDANCE OF Chrysoperla carnea (STEPH.) AND Chrysopa septempunctata WESM. BY USING A LIGHT TRAP AT MANSOURA DISTRICT
}

\author{
Ghanim,
}

Eman A. S. Abd El-Halim**

* Economic Entomology Dept., Fac. of Agric., Mansoura Univ., Egypt.

**Plant Protection Res. Institute, Agric. Res. Center, Dokki Giza, Egypt.

\begin{abstract}
A survey of certain neuropterous predators and the relative abundance of the important neuropterous predatory insects were studied by using a light trap during two successive years at Mansoura district. The obtained results recorded four neuropteruos predators trapped during the two years of study. These species belonging to two families: Chrysopidae and Myrmeleonidae. These predators were namely: Chrysoperla carnea (Steph.) ; Chrysopa septempunctata Wesm.; Cueta variegata Klug. and Palpares cephalotes Klug. The dominant species was $C$. carnea during the two years of investigation. The data showed that $C$. carnea had six peaks in the first year and five peaks in the second year of study. These peaks were recorded in the fourth week of March; fourth week of April; first week of June; third week of July; third week of August and second week of October; while in the second year these peaks were recorded in the first week of April; first week of June, first week of July, first week of August and fourth week of September, respectively. The obtained data revealed that $C$. septempunctata had four peaks in the first years and three peaks in the second years. These peaks were recorded in the first week of June, third week of July, fourth week of August and second week of October, respectively in the first year, Meanwhile, these peaks were found in the second year of study, in the first week June, first week of July and fourth week of August. The statistical analysis assured that, there was a highly positive significant correlations between the biweekly catch of $C$. carnea and $C$. septempunctata and temperature parameters during the two years of study. While, the relative humidity parameters had insignificant effect on the population density of the two predators during the two years of investigations.
\end{abstract}

\section{INTRODUCTION}

Neuropterous insects are fairly diverse and about 4.500 species are already known. These species are found about vegetation and often near bodies of water, since many have aquatic larvae. They feed on fluid materials and various soft-bodied insects. Many species of order group are known as very effective predaceous insects for more than 80 species of insect pests and ten species of mites (Butler and Ritchie , 1978 ; Kharizanov and Babrikova , 1978 ; Kharizanov , 1982; Sengonca and Grooterhorst , 1985; Ghanim et al., 1988 and Abd El-Aziz , 1991). Several investigators had studied the flight activity and population density of certain neuropterous predatory insect species by using the light traps( Hassanein , 1956 ; Honek , 1977; Nielsen , 1977; Tadic , 1979 ; Stang, 1980; Honek and Kraus 1981; 
Ghanim, A. A. et al.

Abd El-Aziz,1991; Gunther, 1991; Szenthiralyi et al. 2001; Soliman, 2004; Deutsch et al. 2005. and Jeyakumare et al. 2007).

Therefore, the purpose of this investigation was to survey the important neuropterous predators and studying the relative abundance and flight activity of Chrysoperla carnea (Steph.) and Chrysopa septempunctata Wesm. at Mansoura district.

\section{MATERIALS AND METHODS}

For studying a survey neuropterous predators and the relative For studying a survey of certain neuropterous predators and the relative abundance of the important neuropterous predatory insects by using a light trap at Mansoura district, samples were taken daily during two years from $1^{\text {st }}$ August 2006 till $31^{\text {st }}$ July 2008.

A Robinson and Robinson (1950) light trap previously proposed by Williams (1923), was used. The trap consists of an inverted metal cone, 24 inches in diameter, and contains six radial vanes projecting two inches above the upper aperture. These vanes obstruct the flight of insects circling or heading for the light and thus reduce their flight speed causing them to stall and fall into the sloping cone and then into the receptacle. At the lower aperture of the cone and in the center of the Vanes, a 250 watt clear mercury vapour lamp is fixed in a socket and so adjusted that its light is unobstructed above the upper structure of the trap. This upper structure is fitted tightly on a barrel-like 24 inches deep receptacle which forms the base of the apparatus. Sodium cyanide, put in a glass jar, is used as killing agent inside the trap. The light trap was set off daily for a period of 12 hours from sunset to sunrise. The trap was placed in the Agricultural Experimental farm of Mansoura University at a height of 3.5 meters. The trap catch was collected every morning and brought to laboratory for identification. The daily catch was separated, identified and counted in the same day. The daily catch was accumulated biweekly. Daily records of temperature and relative humidity of Mansoura district were obtained from the Meteorological Organization, Ministry of Defense and Cairo. These records have been calculated as biweekly means related to the date of accumulated biweekly catch.

Data analysis:

For the purpose of statistical analysis, data were analyzed by using correlation coefficient using computer advanced statistical program Cohort software (Costat 2004).

\section{RESULTS AND DISCUSSION}

\section{Surving neuropterous predators by using a light trap:}

Four neuropterous predators were caught by a light trap during the two years of study belonging to the two families namely: Chrysopidae and Myrmeleonidae. The names and the total numbers of each species together with their percentage to total catch during the two years of investigation are given in Table (1). From this table, it can be seen that the total number of 
7171 neuropterous predator individuals had been trapped by a light trap during the two years of investigation. The total catch of the first year was 3554 individuals, while that of the second year was 3617 individuals. The obtained results showed that most dominant family was Chrysopidae(83.86\%)in 2006/2007and(84.32\%)in 2007/2008. This family was represented by two species, the number and percentages of these species during the two years were as follows :

C. cranea (1654 individuals $=55.47 \%)$ in 2006/2007 (1617 individuals $=53.02 \%)$ in 2007/2008; C. septempunctata $(1328$ individuals $=$ $44.53 \%$ ) in 2006/2007 and (1433 individuals $=46.98 \%$ ) in 2007/2008. The dominant Chrysopidae species among them was C. cranea . In addition , the results showed that family Myrmeleonidae represented $16.14 \%$ and $15.68 \%$ of the total catch in 2006/2007 and 2007/2008 respectively . This family was represented by two species. The numbers and percentages of these species during the two years were as follows : $C$. variegata ( 276 individuals $=48.08 \%$ ) in 2006/2007 and (324 individuals $=57.14 \%$ ) in 2007/2008 ; and $P$. cephalotes (298 individuals $=51.92 \%)$ in $2006 / 2007$ and $(243$ individuals $=$ $42.86 \%$ ) in 2007/2008. Semeira (1980) in France, used a light trap for surveying the Chrysopid predators during the period of Mayt till October 1979. He found that nine species of Chrysopids belonging to four genera were recorded. These included $C$. carnea which represented $15.8 \%$ of the total catch. Similar results were reported by Abd El-Aziz (1991) in Egypt, found that the most dominant family caught by a light trap was family Chrysopidae , as it represented $92.81 \%$ of the total catch , while family Myrmeleonidae formed $7.19 \%$ of the total catch. Deutsch et al. (2005) in France, studied light trapping collections of Chrysopids predator over ten years. They found that the main species were members of the $C$. canea complex. These complex were increased from 38.00 to $72.00 \%$ of the total Chrysopids in samples.

Table (1): Total numbers and percentages of neuropterous predatory insect species cought by a light trap during the two years of study at Mansoura district.

\begin{tabular}{|c|c|c|c|c|c|c|}
\hline \multirow{2}{*}{$\begin{array}{c}\text { Families } \\
\text { and species }\end{array}$} & \multicolumn{3}{|c|}{$2006 / 2007$} & \multicolumn{3}{|c|}{2007 / 2008} \\
\hline & $\begin{array}{c}\text { Total } \\
\text { number } \\
\text { of } \\
\text { species }\end{array}$ & $\begin{array}{c}\% \text { of } \\
\text { species } \\
\text { to family }\end{array}$ & $\begin{array}{c}\% \text { of } \\
\text { species } \\
\text { to total }\end{array}$ & $\begin{array}{c}\text { Total } \\
\text { number } \\
\text { of } \\
\text { species }\end{array}$ & $\begin{array}{c}\text { \% of } \\
\text { species } \\
\text { to family }\end{array}$ & $\begin{array}{c}\% \text { of } \\
\text { species } \\
\text { to total }\end{array}$ \\
\hline Chrysopidae: & & & & & & \\
\hline C. carnea & 1654 & 55.47 & 46.51 & 1617 & 53.02 & 44.71 \\
\hline C. septumpunctata & 1328 & 44.53 & 37.35 & 1433 & 46.98 & 39.62 \\
\hline Total & 2982 & 100 & 83.86 & 3050 & 100 & 84.32 \\
\hline Myrmeleonidae: & & & & & & \\
\hline C. variegata & 276 & 48.08 & 7.76 & 324 & 57.14 & 8.96 \\
\hline P. cephalotes & 298 & 51.92 & 8.38 & 243 & 42.86 & 6.72 \\
\hline Total & 574 & 100 & 16.14 & 567 & 100 & 15.68 \\
\hline \begin{tabular}{|c|} 
General Total \\
\end{tabular} & 3554 & & 100 & 3617 & & 100 \\
\hline
\end{tabular}


Ghanim, A. A. et al.

2. Population density of the two important neuropterous predators caught by a light trap :

A . Chrysoperla cranea:

1. Relative abundance and flight activity of $C$. carnea adults :

Figure (1) shows the relative abundance of $C$. carnea adult in the first year of study. The adult of $C$. carnea start to appear in the fourth week of February, then the population increased gradually and reached the first peak in the fourth week of March. The biweekly catch showed that $C$. carnea had six peaks in the first year of the investigation. Meanwhile in the second year, these peaks were recorded in the fourth week of March, fourth week of April, first week of June, third week of July, third week of August, and in the second week of October, respectively in 2006 / 2007. The highest peak was found in the third week of August .

It can be concluded from Figure (1) that adults of $C$. carnea disappeared completely from the first week of December till the second week of February.
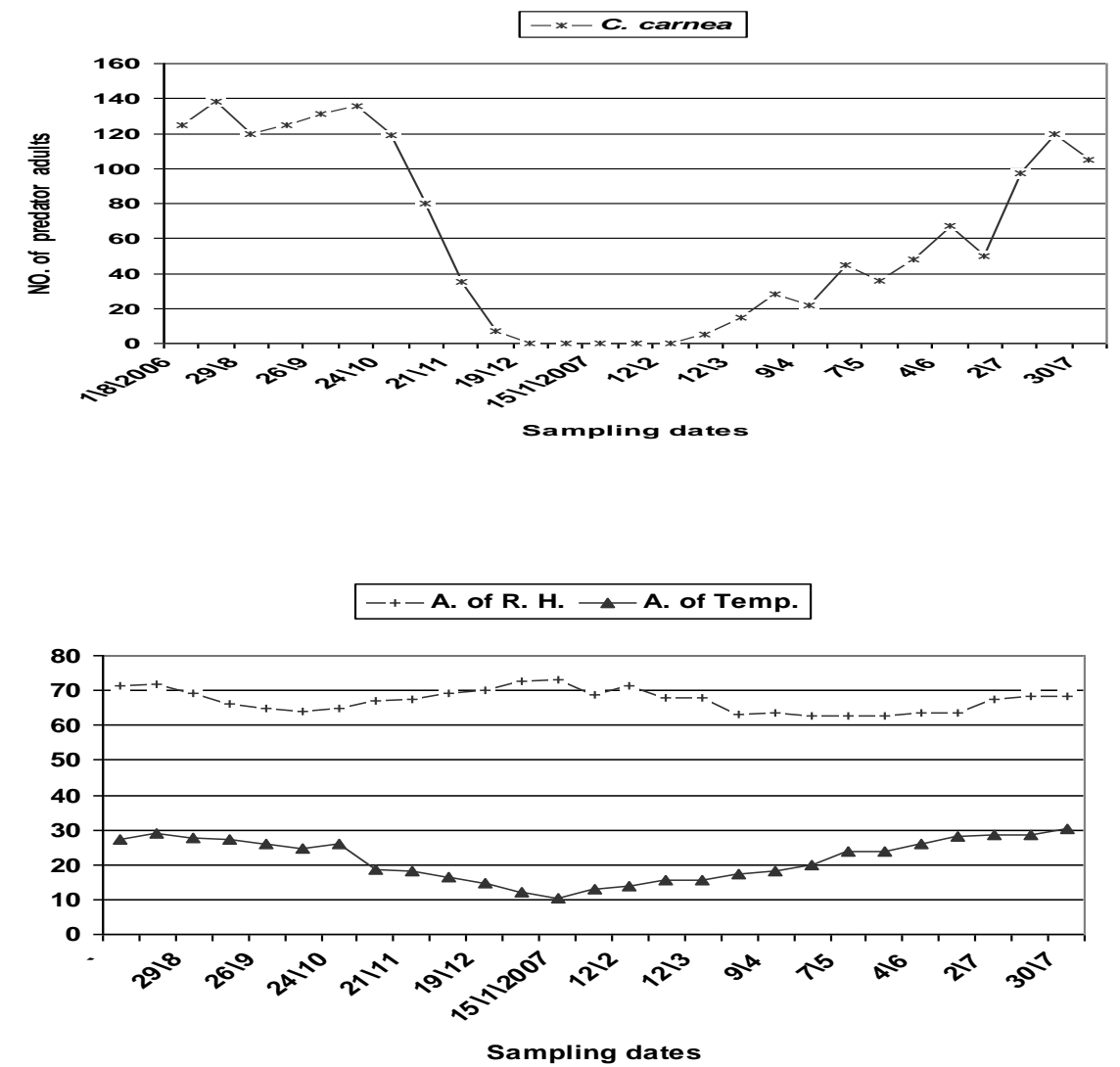

Figure (1) Biweekly catch of $C$. carnea trapped by a light trap during the first year 2006 /2007 at Mansoura district. 
Figure (2) illustrated the population density of $C$. carnea adults in the second year of investigation. The adults of this predator started to appear in a light trap in the second week of February during the second year of study, then the number of biweekly catch increased gradually and reached its first peak in the first week of April . It can be noted that $C$. carnea adult disappeared during the period from the first week of January till the third week of the same month. The biweekly catch showed that $C$. carnea had five peaks in the second year of study. These peaks were found in the first week of April , first week of June ,first week of July, first week of August and fourth week of September. The highest peak was found in the fourth week of September. The highest peak was found in the fourth week of September. It can be seen from Figure (2) that the optimum degree of temperature and relative humidity for $\mathrm{C}$. carnea ranged between $25.43-28.86^{\circ} \mathrm{C}$ and $67.97-$ $71.72 \%$ R.H..

These findings generally are in agreement with the findings of Hassanein (1956) who found that the first appearance of the lacewing fly in the traps was in $16^{\text {th }}$ March and the peaks of the predator population was during May, June and July . In addition, Nielsen (1977), in Denmark stated that the peaks of $\mathrm{C}$. carnea adults activity trapped by light traps were recorded in July and October and most of the individuals were collected in October, but Kharizanov and Dimitrov (1972) in Bulgaria, found that adults of C. carnea were occurred in the field at the end of March and the beginning of April, when the average temperature reaches $12^{\circ} \mathrm{C}$. Abd El-Aziz(1991) in Egypt, recorded five generations for $C$. carnea and the peaks of these generations were found in the third week of May, third week of June, second week of July, second week of August and first week of October. Oresek et al. (2004) in Slovenia surveyed lacewings from $21^{\text {th }}$ April to October 1994 using light traps. They found that , the highest numbers were collected in July (153 adults) and the most frequently caught species were C. carnea and Chrysopa perla .

2. Effect of certain weather factors (temperature and relative humidity)on the population density of $C$. carnea:

The summarized data in Table (2) presented that the simple correlation coefficient between the population density of $C$. carnea (biweekly catch) and max. temp., min. temp., average temp., max. R.H., min. R.H., and average R.H. during the two years of study. The statistical analysis showed that there was a highly significant positive correlations between the biweekly catch of $C$. carnea and the temperature parameters (min.; max. and average tem.) during the two years of study (Table 2).While the relative humidity parameters had insignificant effect on the population density of this predator during the two years of investigations. These findings are in agreement with the findings of Honek and Kraus (1981) in Czechoslovkia who studied a regression analysis of some weather factors affecting a light trap catches of $C$. carnea in Prague. They stated that from July to September, significant correlations were found between catches and temperature parameters. 
Ghanim, A. A. et al.

Figure (2) Biweekly catch of $C$. carnea trapped by a light trap during the second year $2007 / 2008$ at Mansoura district.

Table (2): Simple correlation coefficient between the population density of $C$. carnea and the temperature and relative humidity components in a light trap during The two successive years $2006 / 2007$ and $2007 / 2008$ at Mansoura district.

\begin{tabular}{|c|c|c|c|c|c|c|}
\hline \multirow[t]{2}{*}{ Weather variables } & \multicolumn{3}{|c|}{$2006 / 2007$} & \multicolumn{3}{|c|}{$2007 / 2008$} \\
\hline & $\mathbf{r}$ & $p$ & $\mathbf{s}$ & $\mathbf{r}$ & $p$ & $\mathbf{s}$ \\
\hline Maximum Temp. & 0.8482 & 0.3098 & 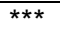 & 0.8717 & 0.2055 & 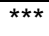 \\
\hline Minimum Temp. & 0.8813 & 0.2805 & $\star \star \star *$ & 0.9209 & 0.9505 & $\star \star \star *$ \\
\hline Average Temp & 0.8718 & 0.1937 & $\star \star \star *$ & 0.9051 & 0.9609 & $\star \star \star *$ \\
\hline Maximum R. H. & -0.0175 & 0.9307 & ns & 0.0380 & 0.8507 & ns \\
\hline Minimum R. H. & -0.1475 & 0.4627 & ns & -0.2182 & 0.2741 & ns \\
\hline Average R. H. & -0.1462 & 0.4666 & ns & -0.1868 & 0.3507 & ns \\
\hline
\end{tabular}

ns $=$ in significant ${ }^{*}=$ significant with varied degree where $r=$ correlation coefficient $p=$ probability $s=$ significant sign. 


\section{B. Chrysopa septempunctata :}

1. Relative abundance and flight activity of $C$. septempunctata adults:

Figure (3) shows the relative abundance of $C$. septempunctata during the first year of study. The adults of this predator started to appear in a light trap in the fourth week of April in the first year of study, then the population density of this predator increased gradually and reached the first peak in the first week of June. The biweekly catch showed that the predator C. septempunctata adults had four peaks in the first year of the investigation. These peaks were recorded in the first week of June, third week of July, fourth week of August and second week of October, respectively in 2006 /2007. The highest peak was found in the four week of August

$$
-+- \text { A. of R. H. } \rightarrow \text { A. of Temp. }
$$
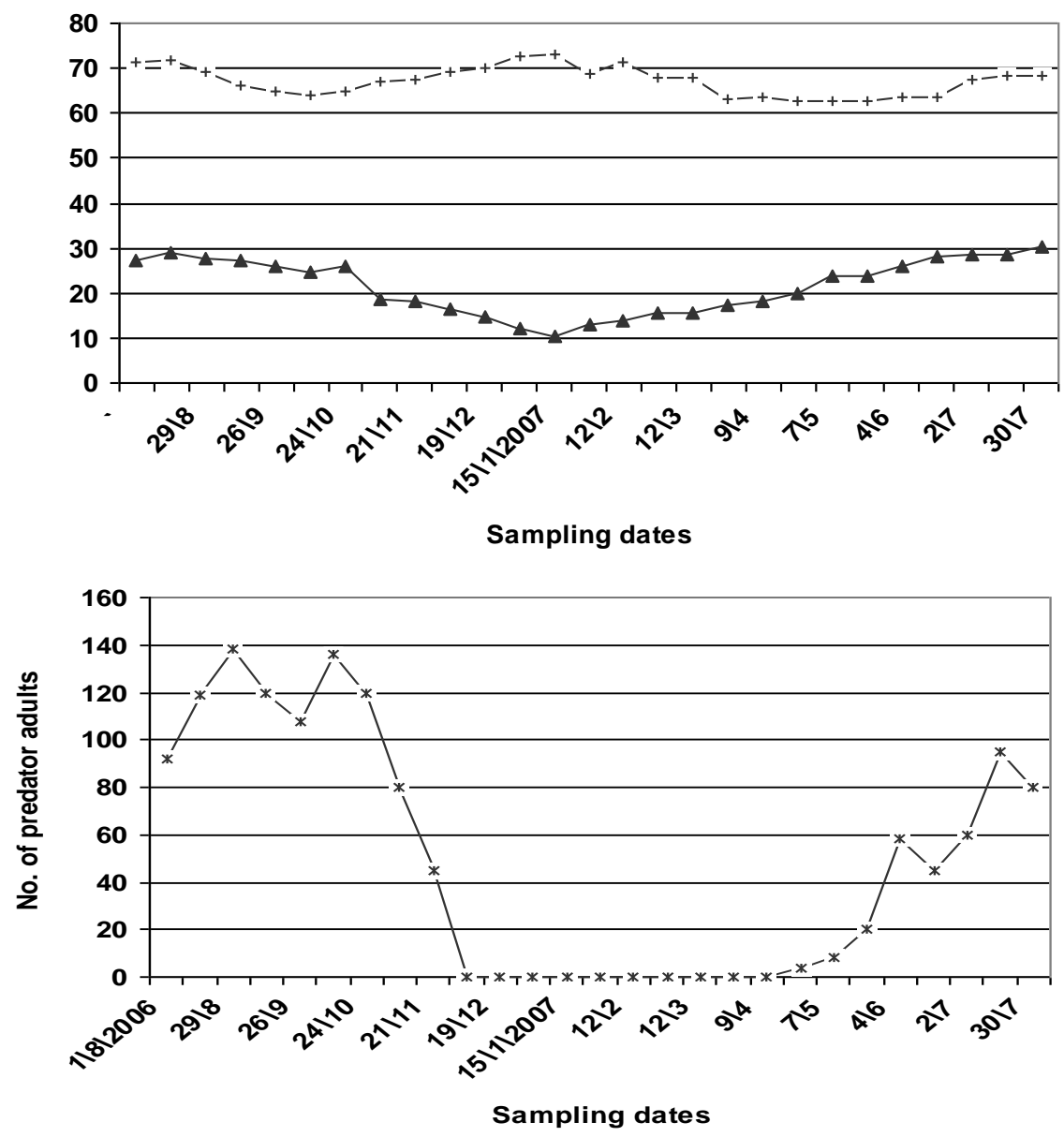

Figure(3) Biweekly catch of $C$. septempunctata trapped by a light trap during the first year 2006/2007 at Mansoura district. 
Ghanim, A. A. et al.

It can be concluded from Figure (3)that adults of C. septempunctata disappeared completely from the first week of December till the second week of April. The size of third and fourth peaks in the first year of study was the highest. That may be referred to the temperature and relative humidity prevailing at this time of the year (July and October) which the average degrees of temperature and relative humidity were between $24.65^{\circ} \mathrm{C}-27.89^{\circ} \mathrm{C}$ and $63.86-69.11 \%$ during the first year of study.

Figure (4) shows the population density of $C$. septempunctata adults in the second year of investigation. It can be noted that $C$. septempunctata adults started to appear in a light trap in the fourth week of April in the second year, then the number of biweekly catch increased gradually and reached its first peak in the first week of June in 2007/2008. The adults of this predator disappeared during the period from the third week of December till the fourth week of April.

Figure (4) Biweekly catch of $C$. septempunctata trapped by a light trap during the second 2007 / 2008 at Mansoura district. 
The biweekly catch showed that $C$. septempunctata had three peaks in the second year of study. These peaks were found in the first week June, first week of July and fourth week of August. The highest peak was found in the fourth week of August. It can be seen from Figure (4) that the optimum degree of temperature and relative humidity for $C$. septempunctata were $29.32^{\circ} \mathrm{C}$ and $68.64 \%$ R.H.. El-Haidari and Aziz (1978) in Iraq , found that $C$. septempunctata had two generations yearly. In addition, Khalil et al. (1980) in Iraq , studied the seasonal abundance of some neuropterous predators during 1976-1977. They mentioned that $C$. septempunctata was the most abundant, but $C$. carnea was less frequently observed. Abd El-Aziz (1991) in Egypt, recorded three generations yearly. The peaks of these generations occurred in the second week of June ,second of July and fourth week of August in 1986. Our results showed there were four peaks in the first year and three peaks in the second year of study.

\section{Effect of certain weather factors (temperature and relative humidity)on the population density of $C$. septempunctata:}

The summarized data in Table (3) showed that the simple correlation coefficient between the population density of $C$. septempunctata (biweekly catch) and max. temp., min. temp., average temp., max. R.H., min. R.H., and average R.H. during the two years of study. The statistical analysis showed that there was highly significant positive correlation between the biweekly catch of $C$. septempunctata and the temperature parameters (min.; max. and average tem.) during the two years of study (Table 3).While the relative humidity parameters had insignificant effect on the population density of this predator during the two years of investigations.

Table (3): Simple correlation coefficient between the population density of $C$. septempunctata and the temperature and relative humidity components during the two successive years (2006/2007 and 2007 / 2008 )at Mansoura district.

\begin{tabular}{|c|c|c|c|c|c|c|}
\hline \multirow[t]{2}{*}{ Weather variables } & \multicolumn{3}{|c|}{2006 / 2007} & \multicolumn{3}{|c|}{2007 / 2008} \\
\hline & $\mathbf{r}$ & $\mathbf{p}$ & $\mathbf{s}$ & $\mathbf{r}$ & $\mathbf{P}$ & $\mathbf{s}$ \\
\hline Maximum Temp. & 0.7542 & 0.5175 & *** & 0.8700 & 0.7586 & 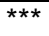 \\
\hline Minimum Temp. & 0.7933 & 0.9628 & *** & 0.9488 & 0.0769 & *** \\
\hline Average Temp & 0.7797 & 0.6319 & *** & 0.9178 & 0.5843 & *** \\
\hline Maximum R. H. & 0.0238 & 0.9061 & ns & 0.0475 & 0.8139 & ns \\
\hline Minimum R. H. & -0.0479 & 0.8123 & ns & -0.1621 & 0.4191 & ns \\
\hline Average R. H. & -0.0440 & 0.8273 & $\mathrm{~ns}$ & -0.1345 & 0.5034 & ns \\
\hline
\end{tabular}

Probability $s=$ significant sign.

\section{REFERENCES}

Abd El-Aziz, M. A. (1991). Studies on certain predators belonging to order Neuroptera in Dakahlia Governorate. M. Sc. Thesis Faculty Agric. Mansoura Univ., Egypt. pp. 108.

Butler, Jr. ; G.D. and Ritchie, Jr . P.L. (1970). Development of Chrysopa carnea at constant and fluctuating temperature. J. Econ. Entomol. 63(6): 1028-1030. 
Ghanim, A. A. et al.

CoHort Software, (2004). CoStat. www. CoHort com. Monterey, California, U. S. A.

Deutsch, B.; Paulian, M. ; Thierry, D.; Canard, M. (2005). Quantifying biodiversity in ecosystems with green lacewing assemblages. Agronomy-for Sustainable-Development. 25(3): 337-343.

El-Haridari , H.S. and Aziz , F.I. (1978). Biology of Chrysopa septempunctata (Chrysopidae: Neuroptera) in Iraq. Yearbook of Plant Production Research, Iraq Ministry of Agric . and Agrarian Reform 1, Ar. pp. 51-53.

Ghanim , A.A. and El-Adel , M.A. (1988). The role beneficial insects in suppression the population of the main insect pests in clover at Mansoura, Egypt. J. Agric. Sci. Mansoura Uni. 13(1):581-591.

Gunther, K. K. (1991). True lacewings from light trapping in the Urban district of Berlin (Insecta, Neuroptera). Entomologische Nachrichten und Berichte. 35(1): 161-170.

Hassanein , M.H. (1956). Nocturnal activity of insects as indicated by light traps . Bull. Soc. ent. Egypte. 40:463-479.

Honek, A. (1977). Annual variation in the complex of aphid predators: investigation by light trap. Acta. Entomologica Bohemoslovaca ,74(5).345-348.

Honek, A.; Kraus, P. (1981). Factors affecting light trap catches of Chrysopa carnea (Neuroptera, Chrysopidae): a regression analysis. ActaEntomologica-Bohemoslovaca. 78(2): 76-86.

Jeyakumar, P. ; Subash, C. ; Amar, S. ; Jat, M. C. Monga, D. (2007). Effects of light trap and lunar cycle on the insects of cotton (Gossypium hirsutum) ecosystem. Indian-Journal-of-Agricultural-Sciences.77(5): 327-328.

Khalil , F.M. , Awadallah , K.T. and Mahmoud , T.T. (1980). Seasonal abundance of natural enemies associated with alfalfa plants in Hammam Al-Alil. Mesopotamia J. Agric. 13(2):213-221.

Kharizanov, A. (1982). The feeding capacity of larvae of the common and seven-spottes lacewings. Rastitelna Zashchita 30(12):8-11.

Kharizanov, A. and Babrikova, T. (1978). Toxicity of insecticides of certain species of Chrysopids . Rastitelna Zashchita 26(5):12-15.

Nielsen, E.S. (1977). Studies on lacewings (Neuroptera : Chrysopidae ) in a Danish beech stand . Entomologiske Meddelelser 45(1) : 45-64.

Oresek, E.;Gomboc, S. ; Devetak, and Milevoj, L (2004). Distribution of lacewings (Chrysopidae) in intensive or chards in the Kostanjevicana Kriki region. 1-Solovenskega- Sadjarskega-Kongresa-z- mednarodnoundelezloo- Krsko, - Slovenia-24-26 Marec ; 497-502.

Robinson , H.S. , and Robinson , P.T.N. (1950). Some notes on the observed behavior of Lepidoptera in flight in activity of light sources together with a of description of a light trap designed to take entomological samples Ent. Gaz. 1: 3-20.

Semeria,-Y (1980). Some chrysopids of Corsica caught by artificial light. Neuroptera-International.1(2): 90-92.

Sengonca, C. and Grooterhorst, A. (1985). The feeding activity of Chrysopa carnea (Step.) on Barathra brassicae L. and Spodoptera littoralis (Boisd.) . Zeitschrift fǜr Angewandte Entomol. 100(2) : 219-223. 
Stange, L. A. (1980). The ant-lions of Florida. I. Genera (Neuroptera: Myrmeleontidae).Entomology-Circular,-Division-of-Plant-Industry,Florida-Department-of-Agriculture-and-Consumer-Services.( 215): 4 pp.

Szentkiralyi, F.; Kazinczy, L.; Lesko, K. (2001). Insect monitoring by the Forestry light trap network (Hungary): seasonal flight activity of antlions (Neuroptera, Myrmeleontidae). Erdeszeti-Kutatasok. 90: 213-230.

Tadic, M. (1979). List of insects captured with ultraviolet light traps during the period 1972-1974 Zastita Bilja. 30(4): 371-382.

Williams , C. B, (1923). A new type of light trap for insects (Bull. 28, Tech and Scientific Service, Ministry of Agriculture, Cairo).

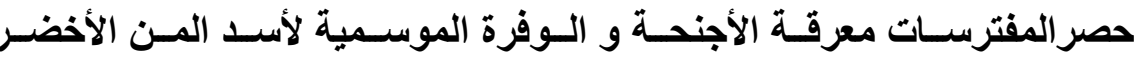

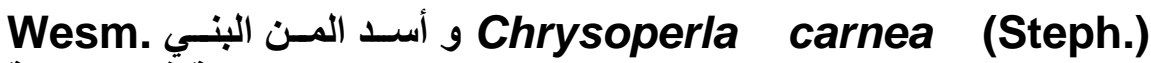

Chrysopa septempunctata المنصورة

عبد البليع عبد الحميد غانم*، محمود السيد النجار**، نجدي فاروق عبد الباقي* و إيمان

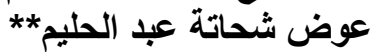

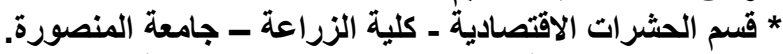

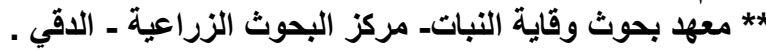

لاراسة حصر المفترسات من رتبة معرقة الأجنحة و الوفرة الموسمية للمفترسات الهامة منها

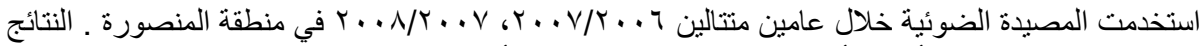

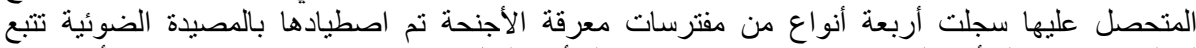

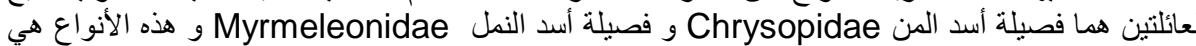

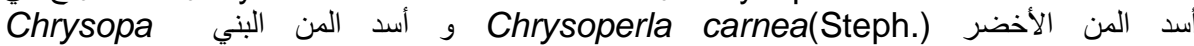
septempunctata Wesm. Palpares cephalotes Klug.

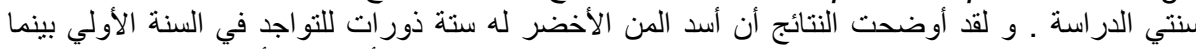

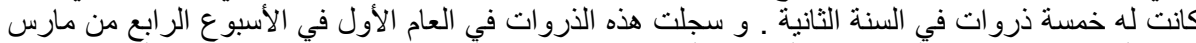

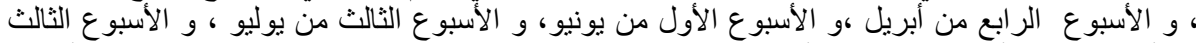

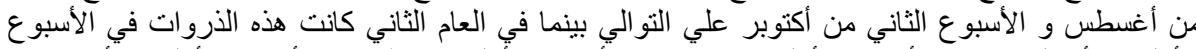

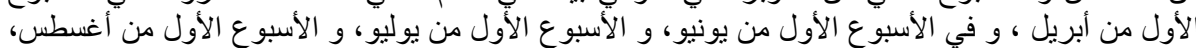

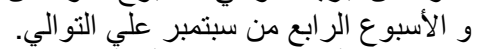

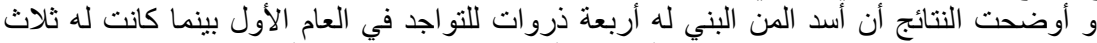

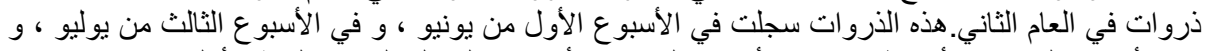

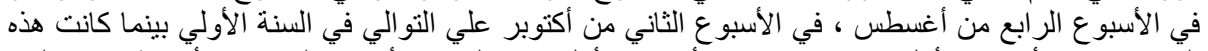

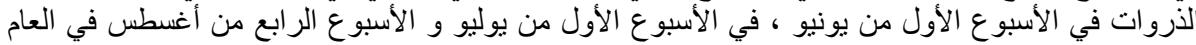

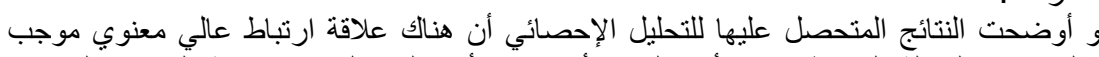

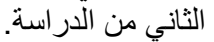

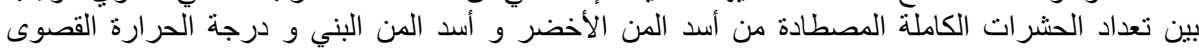

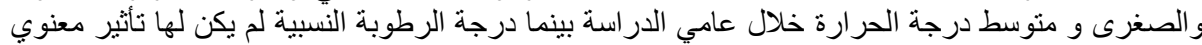
علي الكثافة العددية لهذين المفترسين خلال سنتي الدراسة. 